\title{
An Exploratory Study of Customer Satisfaction with International Student Recruitment Agencies: A Case Study in New Zealand
}

\author{
Shaohua Yang ${ }^{1}$, Xingxing Chen ${ }^{2} \&$ Xiaoli Shen ${ }^{3}$ \\ ${ }^{1}$ Faculty of Business, Information Technology \& Creative Arts, Toi Ohomai Institute of Technology, New \\ Zealand \\ ${ }^{2}$ Business with Finance, Bachelor of Arts (Honours), University of Northumbria at Newcastle, UK \\ ${ }^{3}$ Graduate Diploma in Applied Management, Otago Polytechnic, New Zealand \\ Correspondence: Shaohua Yang, Faculty of Business, Information Technology \& Creative Arts, Toi Ohomai \\ Institute of Technology, New Zealand. E-mail: samuelyang0713@hotmail.com
}

Received: June 14, 2017

doi:10.5539/ijbm.v12n11p130
Accepted: September 30, 2017

Online Published: October 18, 2017

URL: https://doi.org/10.5539/ijbm.v12n11p130

\begin{abstract}
This paper explores customer satisfaction in education service industry (international students' recruitment agents) in New Zealand. To identify the factors that will increase international students' satisfaction, and find possible methods to retain international students, mixed methods were employed in one international agency in Auckland. A total of 100 questionnaires were completed and semi-structured interviews were conducted with international students and education consultants. The findings indicate that professional knowledge, service, personalities and communication are key factors that will influence international students' satisfaction. Moreover, the findings also demonstrate that the increase of consultants' satisfaction results in international students' satisfaction. Establishing high contact with international students is a possible method to retain them. Results are discussed in relation to international students' satisfaction in the context of education service industry. This paper enriches the body of literature on higher education particularly on international student's satisfaction with third parties (international agents). Recommendation for practice that could enhance the understanding of international students' satisfaction, is also discussed.
\end{abstract}

Keywords: Customer satisfaction, Communication, Service, International students, International agents, Recruiting international students

\section{Introduction}

In today's competitive environment, organizations need to establish a good relationship with customers, and also provide professional services for them to improve customer satisfaction. Among academic literature, customer satisfaction has been widely investigated in different types of business industries. Several studies discovered the relationship between service quality and customer satisfaction in banking industry (Ming \& Ing, 2006; Roger, 1996). Other researchers examined the importance of service quality to customer satisfaction in hospitality industry (Janna \& Chandra, 2016; Singh \& Dewan, 2009; Sim, Mak \& Jones, 2006). Nevertheless, relatively little research has investigated customer satisfaction and service quality in the context of international education. In international education sector, international students' satisfaction is significant to higher institutions' success. This sector highlights the importance of destination marketing because it can influence the choice of target international students whether to return to the previous agency and recommend it to others (Arambewela \& Hall, 2009). To expand knowledge in this field, this study is focused on investigating international students' satisfaction in educational services' industry especially in the context of international student's recruitment agents (ISRA) in New Zealand. Due to limited research on this topic, mixed methods were adopted in this study to explore this emerging issue.

Since export in education industry is sustainable 'green' export, it fits well with New Zealand's vision of developing a knowledge-based economy. It also brings many economic and cultural benefits to the New Zealand and its educational institutions (Butcher, 2002). Therefore, New Zealand government encourages the promotion of its educational institutions to overseas market especially via international agencies in international student recruitment for tertiary institutions. Plenty of literature suggests that the use of 
international agents to recruit international students is a tacit marketing approach because tertiary institutions can gain significant returns. For instance, in English speaking countries scholars found that most international students were satisfied with the service provided by international agents because $93 \%$ of the international agents gave away promotional documents, $51 \%$ of the international students were charged for visa application assistance, $29 \%$ of the students consulted with agents and $20 \%$ relied on agents' advice (Kirsch 2014; Archer, 2010; Harris \& Rhall, 1993). In New Zealand, Yang and Akhtaruzzaman (2017) employ a quantitative method in their study and the result shows $44.29 \%$ of international students enrolled in tertiary institutions by using agents because international agents can provide with information about visa application, course enrolment, and immigration policy. However, the findings also reveal that there were still around $30 \%$ of international students who were dissatisfied with the service provided by the international agents because some international agents were not familiar with the knowledge of program offered by institutions, or even delivered misleading information to international students (Yang \& Akhtaruzzaman, 2017). Hence, in order to maintain the reputation of tertiary institutions, international agents need to understand degrees of international students' satisfaction. While previous scholars have conducted quantitative studies on this subject, very few have adopted the exploratory method to examine factors related to international students' satisfaction with their educational agents. It is considered as a gap that the current study attempts to fill in academic literature. Therefore, the aim of this study is to contribute to academic literature on this topic by exploring international students' satisfaction in specific education services' category (international student recruitment agencies) in New Zealand.

\subsection{Research Questions}

Dhat are the key factors that will increase international students' satisfaction with ISRA?

$>$ What kind of service do the international students expect from their consultants in ISRA?

$>$ What are the possible methods to retain international students for ISRA?

\section{Theoretical Framework}

Forsythe (2007) proposes customer satisfaction in Australian residential construction that was developed by applying marketing theory merged with construction concepts. Keith (1960) explains that marketing is to satisfy the needs and demand of consumers, this definition highlighted the importance of customer satisfaction. Rust and Oliver (1994) define customer satisfaction as an extent to which a person believes that an experience creates positive feelings. Thomassen $(2003$, p. 69) defines customer satisfaction as follows: "the perception of the customer as a result of consciously or unconsciously comparing his experiences with his expectations". Based on this definition, Kotler \& Keller (2006) state that customer satisfaction is determined by "the degree to which someone is happy or disappointed with the observed performance of a product in relation to his or her expectations". Performance below expectations leads to a dissatisfied customer, while performance that lives up to expectations brings a satisfied customer. Exceeding expectations leads to a "very satisfied or even pleasantly surprised customer" (Kotler \& Keller, 2003, p. 80). The definition of Zeithaml \& Bitner (2003, p. 86) is slightly different from that of Thomassen: "Satisfaction is the consumer fulfillment response. It is a judgement that a product or service feature, or the product of service itself, provides a pleasurable level of consumption-related fulfillment." The emphasis of Zeithaml and Bitner is thus on obtaining a certain level of satisfaction in relation to purchasing.

However, the above theoretical explanations have been mainly applied to tangible products while evidence available in education service sector is very limited. The definition of Thomassen, which meshes well with the offerings of education service industry and falls into the luxury category, is discussed in this study, given the significance of perception. Sending international students for overseas education is a long process. International students will spend a large sum of money on receiving their education overseas so that they need to have pleasurable experiences with their agents. All agents are required to be professional by overseas education policy and visa policy to ensure the provision of effective responses to inquires of potential international students. Although Zeithaml \& Bitner (like Thomassen) state that customer satisfaction is a reaction to the experience gained and focus on a certain kind of satisfaction, there is no distinction between conscious and unconscious comparisons in their definition. Education service industry needs to fit its mission that focus on assuring a standard quality of service and meet international students' needs.

\section{Study Method}

This study was conducted by adopting mixed methods including questionnaires and interviews which were 
conducted to collect accurate and relevant data as the primary research. Kendall (2008) believes that qualitative interview data often gathered more in-depth insight on participants' attitudes, thoughts and actions. Since the period between the late 19th century (in journalism) and the early 20th century (in the social sciences), the conversational process of knowing has been conceptualized in the name of interviewing. An interview is literally, an interchange of views between two persons, conversing about a subject of mutual interest (Kvale \& Brinkmann, 2008). Considering the research questions in this study, four people were interviewed about their experiences with ISRA. The face-to-face semi-structured interviews were carried out over a two-week period after the questionnaires were completed. Interviews were conducted in two groups, hence international students' interviews and staff (education consultants) interviews. The two international students were selected from questionnaire respondents and the other two interviewees were the staff members (senior education consultants) of ISRA.

Questionnaire survey was adopted in this research. A total of 100 questionnaires were completed. The questionnaires were conducted within one month from $20^{\text {th }}$ October to $20^{\text {th }}$ November in 2016. The survey questionnaire was made up of 6 closed questions and 2 scale based questions. All respondents were Chinese international students who had already arrived in New Zealand. The questionnaires were handed out to the international students along with a detailed survey sheet when international students came to visit ISRA. Because international agencies' industry in New Zealand were too many to cover, researchers only selected a top international agents' organization that contained the largest number of international students. However, before filling out this survey sheet, respondents had been told that they were free to participate or not and were informed of the aim of survey. The collection of questionnaires was conducted via a sealed box at the reception of ISRA.

\section{Results and Discussions}

\subsection{Results of Interviews}

Results were provided by the interviewees with regard to their experiences with their agents and what were the key factors that would increase customer satisfaction in their opinions. The interview schedule consisted of five semi-structured questions. The results are as follows:

Question 1: Can you give me an example of a good experience with your agency

Chinese international students:

Student A said that her agents provided lots of professional information for her when she was confused about which program she should choose. Her counselor was very patient and helped her to analyze not only programs but her future career.

Student B stated that when she first came to New Zealand, she was only 16 years old. In the first three months she could not adapt to living abroad at all and had communication problems with her homestay family. Her agent went visited to her homestay family and talked with the host parents. Furthermore, the counselor enlightened her regularly and helped her to get used to Kiwi life and culture in a short time. She was very grateful to the experience with the agent.

Staff:

Staff $A$ said that the agent held company dinners regularly and all the staff were encouraged to bring families with them.

Staff B said that the team was very cohesive and colleagues were friendly.

Question 2: What do you believe will increase customer satisfaction with your agencies?

Chinese international students:

Student A said that settling various difficulties for her and satisfying her requirements efficiently would increase her satisfaction.

Student B said if the agency could provide "helpful information" for her regularly, it would make her satisfied.

Staff:

Staff A stated that "high quality service" and "strong relationships with customers" may increase customer satisfaction.

Staff B pointed out that "personal charm" influenced customer satisfaction. "If customers appreciate your personality and work attitude, they will actively cooperate with you". 
Question 3: Could you please give examples of the service provided by your agency?

Chinese international students:

Student A listed the services she received as follows: providing useful information about schools and programs, applying schools and student visa for her, and arranging accommodation and airport pick up for her.

Student B stated that the services included taking her to attend placement test and guiding her through the preparation of various application documents.

Staff:

Both staff $A$ and staff $B$ listed all the services provided as follows:

Offering consultation, preparing documents for school application, communicating with both schools and students, guiding students through the preparation of visa materials, applying for student visa, reminding students to finish payment, arranging accommodation for students if required, and caring about students regularly.

Question 4: What do you think is the best way for your agency to communicate with you?

Chinese international students:

Student A said the best way was to keep up with her situation and guide her through the choice of university, program and even future career.

Student B said the best communication was to keep in touch with her and reply to any of her requirement.

Staff:

Staff A said that regularly connecting with customers was the most significant way.

Staff B said the best way was encouraging his customers to "complain" and often listening to customers" "voices and feedback".

Question 5: What was the main problem during the service delivery of your agency?

Chinese international students:

Student A stated that sometimes she felt the email reply was a bit slow.

Student B said that her counselor did not keep in touch with her and in past year, she had only been contacted once.

Staff:

Staff $A$ said that he sometimes could not reach students if students changed phone numbers or did not reply emails. It was a problem.

Staff B stated that some customers switched to other agencies in the process of service delivery. The other problem was frequent unpaid extra work both after work and on weekends

\subsection{Results of the Survey}

As to the structure of the questionnaire, it was made up of 6 closed questions and 2 scale based questions. Customers were asked to answer 6 closed questions by circling one number and complete 2 scale based questions by ticking the most appropriate option. This survey adopted descriptive method and the results were analyzed in the form of tables.

Introductory information

Based on the results of the survey, $60 \%$ of the participants are female and $40 \%$ male.

As shown in Table 1, age groups (percent) of Chinese international students are 18-25 (40\%), under 18 years old (28\%), 25-35 (25\%) and over 35 (7\%). 
Table 1. Age groups of participants

\begin{tabular}{lllll}
\hline Age & Frequency & Percent & Valid Percent & Cumulative Percent \\
\hline under 18 & 28 & 28.0 & 28.0 & 28.0 \\
$18-25$ & 40 & 40.0 & 40.0 & 68.0 \\
$25-35$ & 25 & 25.0 & 25.0 & 93.0 \\
$35+$ & 7 & 7.0 & 7.0 & 100.0 \\
Total & 100 & 100.0 & 100.0 & \\
\hline
\end{tabular}

As suggested in Table 2, 45\% of the participants have studied in New Zealand for 1-3 years. Only 5\% have lived in New Zealand for more than 5 years. Almost half of the Chinese international students have studied in New Zealand either less than one year $(23 \%)$ or 3-5 years $(27 \%)$.

Table 2. Time living in New Zealand

\begin{tabular}{lllll}
\hline Living years & Frequency & Percent & Valid Percent & Cumulative Percent \\
\hline less than one year & 23 & 23.0 & 23.0 & 23.0 \\
1-3 years & 45 & 45.0 & 45.0 & 68.0 \\
3-5 years & 27 & 27.0 & 27.0 & 95.0 \\
more than 5 years & 5 & 5.0 & 5.0 & 100.0 \\
Total & 100 & 100.0 & 100.0 & \\
\hline
\end{tabular}

Table 3 indicates the relationship between genders and preferred ways of communication. Females preferred email and text messages, while, males preferred phone calls.

Table 3. Communication methods preferred by different genders

\begin{tabular}{llllll}
\hline Gender & Email & Phone call & Text message & Visit & Total \\
\hline Male & 25 & 2 & 10 & 3 & 40 \\
Female & 42 & 1 & 14 & 3 & 60 \\
Total & 67 & 3 & 24 & 6 & 100 \\
\hline
\end{tabular}

Questionnaire: Data Analysis and Discussion

Question 1: How frequently does your agency contact you?

Table 4. The frequency of contact with agency

\begin{tabular}{lllll}
\hline & Frequency & Percent & Valid Percent & Cumulative Percent \\
\hline Once a month & 44 & 44.0 & 44.0 & 44.0 \\
Twice half a year & 41 & 41.0 & 41.0 & 85.0 \\
Once a year & 10 & 10.0 & 10.0 & 95.0 \\
Less than once a year & 5 & 5.0 & 5.0 & 100.0 \\
Total & 100 & 100.0 & 100.0 & \\
\hline
\end{tabular}

Table 4 shows that $44 \%$ participants were contacted by consultants once a month and $41 \%$ participants twice half a year in the past few years. The students choosing once a year accounted for $10 \%$ while less than once a year $5 \%$.

Question 2: What method of communication do you prefer? 
Table 5. Communication method analysis

\begin{tabular}{lllll}
\hline Method & Frequency & Percent & Valid Percent & Cumulative Percent \\
\hline Email & 67 & 67.0 & 67.0 & 67.0 \\
Phone call & 3 & 3.0 & 3.0 & 70.0 \\
Text message & 24 & 24.0 & 24.0 & 94.0 \\
Visit & 6 & 6.0 & 6.0 & 100.0 \\
Total & 100 & 100.0 & 100.0 & \\
\hline
\end{tabular}

Table 5 indicates more than half of the participants $(67 \%)$ have chosen contact by email. Contact by call occupies the least share, only $3 \% .24 \%$ of the participants preferred text message and $6 \%$ participants preferred paying a visit to agencies by themselves.

Question 3: How important are these factors for consulting agencies?

Table 6. Important factors analysis

\begin{tabular}{lllll}
\hline & $\mathrm{N}$ & Range & Mean & Std. Deviation \\
\hline Professional knowledge & 100 & 3 & 3.49 & .659 \\
Service & 100 & 3 & 3.41 & .726 \\
Communication skills & 100 & 3 & 3.21 & .686 \\
Reputation & 100 & 4 & 3.03 & .745 \\
Personality of counselor & 100 & 4 & 2.84 & .788 \\
Brand of organization & 100 & 3 & 2.29 & .701 \\
Location & 100 & 3 & 1.93 & .649 \\
Valid N (listwise) & 100 & & & \\
\hline
\end{tabular}

Table 6 presents that seven items were scored on a 5-point scale started by 1(not important) to 5(extremely important). "N" represents the total number of respondents. "Range" represents the difference between the highest and the lowest values in the data set. "3" means important and " 4 " very important. "Mean" represents the sum of all the data values divided by the number of values. "Std. Deviation" represents the positive square root of the variance. According to Table 3, from a customer's standpoint, the top three key factors are professional knowledge of counselor, service of consulting agency and communication skills with customers. It is proved that these factors are the most significant to international students in the process of consulting service.

Question 4: What do you think of your agent's performance regarding each factor?

Table 7. Agents' performance analysis

\begin{tabular}{lllll}
\hline & $\mathrm{N}$ & Range & Mean & Std. Deviation \\
\hline Communication skills & 100 & 3 & 2.57 & .795 \\
Personality & 100 & 3 & 2.40 & .603 \\
Service & 100 & 3 & 2.37 & .774 \\
Professional knowledge & 100 & 3 & 2.34 & .768 \\
Brand & 100 & 2 & 2.33 & .637 \\
Reputation & 100 & 3 & 2.27 & .633 \\
Location & 100 & 2 & 2.19 & .615 \\
Valid N (listwise) & 100 & & & \\
\hline
\end{tabular}

In Table 7, seven items were scored on a 5-point scale started by 1 (very satisfactory) to 5 (very dissatisfactory). In the Range column, " 2 " is quite satisfactory and " 3 " is neither satisfactory nor dissatisfactory. Compared with question 3, question 4 is more specific and targeted. According to their previous experience, the participants have scored each item, which was then received and processed by ISRA. The items were scored by the participants based on service performance, some well performed and some needing improvement. Therefore, it is concluded that the top three well performed factors are communication skills, personality and service. 
Question 5: Have you asked your agency about other information besides on New Zealand education?

Table 8. Whether ask for other information

\begin{tabular}{lllll}
\hline & Frequency & Percent & Valid Percent & Cumulative Percent \\
\hline Yes & 54 & 54.0 & 54.0 & 54.0 \\
No & 23 & 23.0 & 23.0 & 77.0 \\
Not sure & 23 & 23.0 & 23.0 & 100.0 \\
Total & 100 & 100.0 & 100.0 & \\
\hline
\end{tabular}

Table 8 demonstrates that more than half of the respondents (54\%) have asked not only professional educational questions but other kinds of information. 23\% respondents answered "no" and the remaining (23\%) were not sure whether they asked for other information or not.

Question 6: What's the frequency of contact with your agency that makes you comfortable?

Table 9. Contact frequency analysis

\begin{tabular}{lllll}
\hline Contact frequency & Frequency & Percent & Valid Percent & Cumulative Percent \\
\hline Regularly & 63 & 63.0 & 63.0 & 63.0 \\
At any time & 9 & 9.0 & 9.0 & 72.0 \\
Occasionally & 28 & 28.0 & 28.0 & 100.0 \\
Total & 100 & 100.0 & 100.0 & \\
\hline
\end{tabular}

In Table 9, 63\% of the students would like to contact their consultant regularly. Only 9\% would like to be reached at any time. Therefore, in total $72 \%$ of the international students preferred contact with their consultant in the process of service. Only $28 \%$ stated that they wanted to be contacted occasionally.

Question 7: Effects of age on preferred communication method

Table 10. Effects of age on preferred communication method

\begin{tabular}{llllll}
\hline Into which age group do you fit? & Email & Phone call & Text message & Visit & Total \\
\hline Under 18 & 6 & 0 & 22 & 0 & 28 \\
$18-25$ & 38 & 0 & 1 & 1 & 40 \\
$25-35$ & 23 & 1 & 0 & 1 & 25 \\
$35+$ & 0 & 2 & 1 & 4 & 7 \\
Total & 67 & 3 & 24 & 6 & 100 \\
\hline
\end{tabular}

Table 10 indicates that the age groups of 18 25 and 25 35 preferred communicating by email. The age group under 18 years old, for whom text message was the best, showed distinctly different preference from other three age groups. Furthermore, respondents over 35 years old were more likely to communicate face to face.

Question 8: Effects of age on professional knowledge / service / communication skills

Table 11. Factors effects of age

\begin{tabular}{llll}
\hline & Mean & Std. Deviation & $\mathrm{N}$ \\
\hline Into which age group do you fit? & 2.11 & .898 & 100 \\
Professional knowledge & 3.49 & .659 & 100 \\
Service & 3.41 & .726 & 100 \\
Communication skills & 3.21 & .686 & 100 \\
\hline
\end{tabular}

Table 11 indicates that the coefficient of professional knowledge is significant at the 0.05 level and the coefficient of service is significant at the 0.01 level. Therefore, it is suggested that as age increases, requirements for professional knowledge and service quality rises. On the other hand, the coefficient of communication skills 
is significant at the 0.05 level but is negative, which suggests that as age increases, needs for communication skills decreases.

Question 9: Effects of age on agents' communication skills / personality of counselor / service

Table 12. Age group (agents) with effects factors analysis

\begin{tabular}{llll}
\hline & Mean & Std. Deviation & N \\
\hline Into which age group do you fit? & 2.11 & .898 & 100 \\
A's communication skills & 2.57 & .795 & 100 \\
A's personality of counselor & 2.40 & .603 & 100 \\
A's service & 2.37 & .774 & 100 \\
\hline
\end{tabular}

Table 12 shows that the coefficient of agents' service is significant at the 0.05 level and negative. It suggests that as age increases, satisfaction degree with agents' service decreases.

\section{Discussion}

To answer the research questions, findings as well as the qualitative and quantitative data analyses are discussed in this study. However, in this study, not all results of interviews and tables were presented, conversely only main questions appropriate to research questions were covered.

In question 1 of the interview, Student A stated that the consultant was very patient to analyze the programs. When international students were confused with the selection of program, agencies always provided effective information for their decision-making on study program. Students B said she had difficulty in communicating with kiwi homestay family. Her consultant went to help communicate with her homestay parents. The consultant also taught her about kiwi culture. In question 2 of the interview, student A said that agencies should have capability to solve their problems on enrolment. This answers the research question "What services do the international students expect from their consultants in ISRA?" International students expect that agencies are able to offer services such as providing effective information on programs, teaching kiwi culture, helping communication with kiwi homestay family and solving their problems of enrolments.

Based on staff B's answer to question 4 of the interview, he often encouraged his students to complain about agents' service. According previous studies, Ovenden (1995) stresses that organizations must be aware of how well or badly their customers were treated. Customers rarely complain, and when someone does, it might be too late to retain that customer. The relationship between customer complaints and customer satisfaction has been investigated by Nyer in 2000. He found that for most dissatisfied customers, inspiring them to complain would improve their satisfaction. The consistency of the results of the interviews with the literature will answer the research question "What are the key factors that will increase international students' satisfaction with ISRA?" Encouraging international students to complain could result in the increase of their satisfaction.

In question 5 of the interview, another staff said that extra work at weekends without compensation was also a problem for him in this kind of consulting service industry. Literature suggests that improvements in staff wages and working environment may enhance employees feeling of ownership of the service encounter, and thus leading to high customer satisfaction (Bowen and Lawler, 1992). This result is also consistent with findings of Heskett, Jones, Loveman, Sasser and Schlesinger (1994). They confirmed that enhancing employee satisfaction could generate improved service quality and thus resulting in elevated customer satisfaction. This result will answer research question "What are the key factors that will increase international students' satisfaction with ISRA?" Increasing wages of consultants and enhancing consultant satisfaction will increase international students' satisfaction. In the question 5, Student A stated that sometimes international students did not get prompt responses from their agencies by email. Staff A said that it was hard to contact to international students when they changed phone numbers or email addresses. Therefore, to retain international students, agencies need to updated international students' profile (personal contact information) and reply international students in time by email. These ideas also answer research question "What are the possible methods to retain international students with ISRA?"

The results of the survey indicate that more than half of the international students feel satisfied and comfortable when ISRA staff contact them regularly. This is why international students' satisfaction can be improved by building strong and good relationships because high and low frequency contact may make distinct differences to customer experiences. 
Based on the survey, this study discovers the relationship between demographic factor (age) and customers' preferred communication methods. Table 2 indicates that the majority of the international students are more likely to communicate with their agencies by email. Furthermore, Table 7 shows that students aged between 18 and 35 years old would like to connect with their agencies by email. For ISRA, daily email communication is a basic business content and work procedure, which is definitely a significant way to communicate with international students with the development of technology. However, respondents over 35 years old are more willing to communicate face to face.

Based on the factor analysis in Table 3, it is presented that the top three key factors in the ranking, i.e. professional knowledge, service and communication skill, are significant to international students in process of consulting. In Table 4 descriptive approach is applied to the statistical analysis of agents' performance for each factor and it turns out that, the three well performed factors are communication skills, personality and service. The result suggests that international students seek advice from others who are knowledgeable about enrolment. International agents need to be approachable with international students. This can answer research question "What are the key factors that will increase international students' satisfaction with ISRA"? Professional knowledge, professional service, attractive personality and good communications skill will increase international student's satisfaction for ISRA.

Additionally, Table 5 shows that more than 50 percent of the international students have not only asked professional education questions but also other questions. For ISRA, it is very important to provide other kinds of information for international student's bedsides that on education. Consultants are required to get hold of other information regarding students' life, and job opportunity in New Zealand. These ideas are associated with research question "What services do the international students expect from their consultants in ISRA?" International students expect that agencies can provide other service such as offering information regarding students' life and job opportunities here.

In addition, this paper also explores the relationships between demographic factor (age) and, professional knowledge, service and communication skills respective. Results from Table 8 and Table 9 imply that as age increases, the importance of professional knowledge and service for customers' increases. On the other hand, as age increases, the importance of communication skills decreases. This research indicates that customers are more focused on communication skills, personality of their counselors and services. In addition, based on the results of this research, with the growth of age, customer satisfaction with service quality delivery decreases. There are both expected findings and unexpected findings appearing. An unexpected finding concerned is the relationship between demographic factor (age) and, communication and service. However, these results indicate that demographic factor has an impact on service and communication, leading to different degrees of customer satisfaction. Therefore, in terms of elevating overall customer satisfaction, service delivery and communication seem to be associated with demographic factor. From a managerial point of view, age influences communication and service delivery and thus leading to different levels of customer satisfaction.

\section{Conclusions and Implication}

Findings of this study indicate that professional knowledge, professional service, attractive personalities and good communicating skill can increase international student's satisfaction with ISRA. International students expect that agencies to provide such kind of service including teaching kiwi culture, delivering job opportunities' information and solving their problem of enrolments. As consultants, the best possible way to retain international students for ISRA is to keep close contact with them and update their profile more frequency. Additionally, the results also suggest that improving consultants' satisfaction will result in international students' satisfaction. In this intensified competition market, New Zealand higher education providers should rely on international agencies for recruiting international students. If international students are satisfied with the service provided by international agents, both parties (international agencies, higher education providers) will earn a good reputation and improve marketing performance.

Through the comparison of the coefficients, knowledge, service and communication skills are the three most significant factors that will influence international students' satisfaction from their perspective. In order to maintain a good number of international students, the results suggest that ISRA should organize workshops to train their education consultants regularly to enhance their professional knowledge of enrolment criteria, visa application and employment opportunities in New Zealand. Being motivated to contact potential international students is necessary, because it will ensure the degree of staff communication skill like engaging in interactive campaigns with potential international students. The study findings also emphasize that international students are more likely to have stable relations with their international inquiry international agents. Service delivery of the 
agents are a set of ongoing processes of dealing with international students' requests, suggestions and complaints. In other industries both customers and service firms can not forecast how long it will last and when the service delivery will be finished. Therefore, the most important thing for ISRA is delivering the service regularly, never breaking the promise, caring about customers, pleasing clients and always supporting international students. Listening to international students' voice and collecting their feedback are good approaches to improve service quality and increase international students' satisfaction. Consequently, organizational reputation will be earned and the number of international students in ISRA will be increased.

This investigation has a range of theoretical and practical contributions. First, it helps to understand the factors that can contribute to customer satisfaction in the context of education service. It enriches the body of higher education literature on international students' satisfaction with third parties (international agencies). This study also supplements the small group of exploratory studies on theoretical explanation in education service industry by providing empirical evidence. The knowledge of customer satisfaction is also discussed in ISRA industry in order to gain more understanding of how international students think of the communication with and services of international agencies. The findings of this study have practical implications as well. Taking the results of this study as an example, associations appear how international agents can increase international student's satisfaction and find a possible method to retain them. It would also help professional marketing staff in ISRA to contribute their marketing strategic formulation and help to achieve a good result of international students' recruiting.

\section{Limitations}

There are several limitations within this study. First, the research is to find out what the key factors that will increase customer satisfaction at the top one International Student Recruitment Agency (ISRA) are. Therefore, the items listed in this paper are not designed to include all possible factors. Further research can be conducted in more ISRA organizations with the aim to expand knowledge of the improvement of international students' satisfaction. Additionally, agent theory might be explored and discussed in international high education sectors. This paper is limited and focused on the main factors to answer the questions. There must be other factors that can affect international students' satisfaction. In addition, the methodology might be considered as a limitation. If more questionnaires were completed and the survey duration was lengthened, the results might be improved in terms of inherent reliability and validity of the measures used. Due to the limitation of sample size, further research using a different sample set would add to the generalizability of the findings. Finally, there are a number of data that can be gathered to analyze, but due to limited research area, only the items linked to customer satisfaction were analyzed.

\section{Acknowledgement}

As a corresponding author, I would like to express my appreciation to my ex-girlfriend (Hongxia Qi) who is a Ph.D student at Victoria University of Wellington. Without your comments on this paper, this project might not be achieved. I also extend my heartfelt thanks to Jing Su from Tianjin Foreign Studies University for your editing my work. Finally, we very much appreciate the contribution and interest of participants in this study.

\section{References}

Archer, W., \& Winters, J. (2011). Global perspectives of challenges to the international student recruitment and enrolment experience. Paper presented at the Annual European Association for International Education Conference, Copenhagen, Germany.

Bejou, D., Wray, B., \& Ingram, T. N. (1996). Determinants of relationship quality: an artificial neural network analysis. Journal of Business Research, 36(2), 137-143.

Berkman, H. W., \& Gilson, C. (1986). Consumer Behavior: Concepts and Strategies (3rd ed.). Kent, Boston.

Bowen, D. E., Edward, E., \& Lawler, III. (1992). The Empowerment of Service Workers: What, Why, How, and When. Sloan Management Review, 33, 31-39.

Butcher, A.P. (2002). No place like home? The experiences of South-East Asian international University students in New Zealand and their re-entry into their country of origin (Unpublished doctoral dissertation). Department of Sociology, Massey University, New Zealand.

Forsythe, P. J. (2007). A conceptual framework for studying customer satisfaction in residential construction. Construction Management and Economics, 25(2), 171-182. https://doi.org/10.1080/01446190600771439

Harris, D. R., \& Rhall, T. M. (1993). Survey of international students, Department of Employment Education and Training, Canberra, Australia. 
Heskett, J. L., Jones, T. O., Loveman, G. W., Sasser, W. E. Jr., \& Schlesinger, L. A. (1994). Putting the serviceprofit chain to work. Harvard Business Review, 72(2), 164-174.

Husyanthy, V., \& Senthilnathan, S. (2012). Customer satisfaction in terms of physical evidence and employee interaction. IUP Journal of Marketing Management, 11(3), 7-24.

Jana, A., \& Chandra, B. (2016). Mediating role of customer satisfaction in the mid-market hotels: An empirical analysis. Indian Journal of Science \& Technology, 9(1), 1-16. https://doi.org/10.17485/ijst/2016/v9i1/81973

Kendall, L. (2008). The conduct of qualitative interview: Research questions, methodological issues, and researching online. In J. Coiro, M. Knobel, C. Lankshear \& D. Leu (Eds.), Handbook of research on new literacies (pp. 133-149). New York: Lawrence Erlbaum Associates.

Kirsch, E. M. (2014). The use of agencies in international student recruitment: International education professional's opinions. SIT Graduate Institute, Brattleboro, Vermont. Retrieved from http://digitalcollections.sit.edu/capstones/2635/

KotleR, P., \& Keller, K. L. (2006). Marketing Management (12th ed). Prentice Hall, New Jersey, USA.

Kvale, S., \& Brinkmann, S. (2008). Interviews: Learning the craft of qualitative research interviewing (2nd ed.). Thousand Oaks, CA: Sage.

Levesque, T., \& Gordon H.G. (1996). Determinants of customer satisfaction in retail banking. International Journal of Bank Marketing, 14(7), 12-20. Retrieved from https://doi.org/10.1108/02652329610151340

Ming, C. L., \& Ing, S. H. (2005). Relationships among service quality, customer satisfaction and profitability in the taiwanese banking industry. International Journal of Management, 22(4), 635-648. Retrieved from https://search.proquest.com/docview/233229927? accountid=14782

Nyer, P. U. (2000). An Investigation into whether complaining can cause increased consumer satisfaction. Journal of Consumer marketing, 17(1), 9-19. Retrieved from http://www.emeraldinsight.com/doi/abs/10.1108/07363760010309500

Ovenden, A. (1995). Keep your customers happy and your competition will slowly fade away. The TQM Magazine, 7(1), 46-49.

Patterson, P. G., \& Smith, T. (2001). Relationship benefits in service industries: a replication in a Southeast Asian context. Journal of Services Marketing, 15(6), 425-443.

Roger, H. (1996). The relationships of customer satisfaction, customer loyalty, and profitability: an empirical study. International Journal of Service Industry Management, 7(4), 27-42.

Rust, R.T., \& Oliver, R.L. (1994). Service quality: insights and managerial implications from the frontier. In Rust, R. T. \& Oliver, R. L. (Eds), Service quality: New directions in theory and practice, 241-68.

Sim, J., Mak, B., \& Jones, D. (2006). A model of customer satisfaction and retention for hotels. Journal of Quality Assurance in Hospitality \& Tourism, 7(3), 1-23. http://dx.doi.org/10.1300/j162v07n03_01

Singh, U., \& Dewan, J. (2009). Hotel management. New Delhi: APH Pub. Corp. In association with Indian Institute of Management.

Terry, B. D., \& Israel, G. D. (2004). Agent performance and customer satisfaction. Journal of Extension, 42(6). Retrieved from http://www.joe.org/joe/2004december/a4.shtml.

Yang, S., \& Akhtaruzzaman, M. (2017). Effective marketing techniques in recruiting international students: evidence from a tertiary institute in New Zealand. Journal of Engineering and Applied Sciences, 12(2), 336-352. Retrieved from http://docsdrive.com/pdfs/medwelljournals/jeasci/2017/336-352.pdf

Zeithaml, V. A., \& Bitner, M. J. (2003). Service marketing: integrating customer focus across the firm. New York: McGraw-Hill Higher Education.

\section{Copyrights}

Copyright for this article is retained by the author(s), with first publication rights granted to the journal.

This is an open-access article distributed under the terms and conditions of the Creative Commons Attribution license (http://creativecommons.org/licenses/by/4.0/). 